Review

\title{
Why Continue Studying HRP2 and HRP3 in Malaria?
}

\author{
${ }^{1}$ María Luz Gunturiz, ${ }^{2}$ Pablo Enrique Chaparro, ${ }^{3}$ Gabriel Carrasquilla and ${ }^{3}$ Mónica Marcela Jiménez \\ ${ }^{1}$ Public Health Research Division, National Institute of Health, Bogotá, D.C., Colombia \\ ${ }^{2}$ National Health Observatory Division, National Institute of Health, Bogotá, D.C., Colombia \\ ${ }^{3}$ Santa Fe de Bogota Foundation, Bogotá, D.C., Colombia
}

\author{
Article history \\ Received: 23-06-2020 \\ Revised: 22-07-2020 \\ Accepted: 22-08-2020 \\ Corresponding Author: \\ María Luz Gunturiz \\ Public Health Research \\ Division, National Institute of \\ Health, Bogotá, D.C., Colombia \\ Email: mgunturiz@ins.gov.co
}

\begin{abstract}
The main malaria control strategy is rapid and accurate diagnosis followed by effective treatment. The quality of the diagnosis is relevant, since an erroneous diagnosis can generate an increase in morbidity and mortality significantly. The World Health Organization (WHO) has recommended that all patients with suspected malaria be diagnosed by microscopy or a Rapid Diagnostic Test (RDT) before treatment. Microscopy and RDT are the main options for diagnosing malaria in the field and in remote areas of endemic countries. This is in line with pillar 1 of the elimination strategy "Achieve universal access to malaria prevention, diagnosis and treatment". Most of the RDTs available on the market detect an antigen from the parasite produced throughout the life cycle of $P$. falciparum; this corresponds to the Histidine-Rich Protein 2 (HRP2). In general, HRP2-based RDTs are more sensitive and stable than those based on other Plasmodium antigens, making them the best choice in most endemic countries where $P$. falciparum malaria predominates. In this review we present evidence on the genetic variability of PfHRP2 and 3 and its potential effect on the efficacy of rapid tests routinely used to diagnose malaria and as main methodological tool elimination programs worldwide.
\end{abstract}

Keywords: Malaria, Plasmodium, Diagnostic Test, Immunologic Tests

\section{Introduction}

In Colombia, malaria is considered a public health problem, it is estimated that at least $70 \%$ of the territory has adequate ecological conditions for the transmission of the disease; and in the Urabá - Bajo Cauca - Alto San Jorge; the Pacific coast and in the OrinoquiaAmazonia regions reported the highest index of the disease (Osorio et al., 2004; Padilla et al., 2011; 2015; Moreno et al., 2017).

Table 1 presents the situation of malaria worldwide, in the Americas region and in Colombia.

Once the suspicion of malaria infection is established, it is essential to carry out a rapid, accurate and reliable diagnosis. In this way, the best treatment can be found and administered as soon as possible to avoid aggravation of the patient's symptoms.

The (World Health Organization, 2018) recommends Rapid Diagnostic Tests (RDTs) as a good alternative malaria-diagnosis method in remote parts and as part of the elimination strategy worldwide. The majority of commercial RDTs currently available detect the Plasmodium falciparum Histidine-Rich Proteins (HRPs).
HRP2-based tests have been preferred in areas where $P$. falciparum is predominant, due to a higher reported sensitivity (Houzé et al., 2009).

\section{Rapid Diagnostic Tests (RDTs)}

RDTs for malaria are lateral flow immunochromatographic tests that detect specific circulating antigens produced by malaria parasites (Moody, 2002). There are at least 25 commercial RDT products on the market, some of which detect only Plasmodium falciparum, while others detect $P$. falciparum plus 1 or more other species of human Plasmodium. The most commonly targeted antigens are histidine-rich protein 2 (HRP2), which is specific for Plasmodium falciparum, Plasmodium Lactate Dehydrogenase (pLDH), which is present in all Plasmodium species. Currently available tests detect one or both antigens simultaneously (Houzé et al., 2009) and there is also some evidence that RDTs that detect HRP or HRP/LDH are more heat stable than tests based on pLDH (Chiodini et al., 2007) and aldolase only (Baker et al., 2005). 
Table 1: Situation of malaria worldwide, in the Americas region and in Colombia

\begin{tabular}{|c|c|c|c|}
\hline Variable & Malaria in the world & Malaria in the Americas & Malaria in Colombia \\
\hline $\begin{array}{l}\text { Countries and } \\
\text { regions affected } \\
\text { by malaria }\end{array}$ & $\begin{array}{l}\text { It affects more than } 100 \\
\text { countries in the world } \\
\text { and } 40 \% \text { of the world } \\
\text { population in risk of contracting } \\
\text { it. } 86 \% \text { of the world's cases } \\
\text { are in sub-Saharan Africa }\end{array}$ & $\begin{array}{l}\text { Endemic-epidemic in } 21 \\
\text { countries. Most of the cases in } \\
\text { Venezuela, Brasil, Colombia, } \\
\text { Perú, Haiti y Guyana } \\
\text { (Organización Mundial de la } \\
\text { Salud, 2019). }\end{array}$ & $\begin{array}{l}\text { Most of the cases occur in } \\
\text { the departments of Chocó, } \\
\text { Nariño, Córdoba, Antioquia, } \\
\text { Norte de Santander (Instituto } \\
\text { Nacional de Salud, 2019). }\end{array}$ \\
\hline People at risk & 4 billion people at risk & $\begin{array}{l}132 \text { million people at risk } \\
\text { (Organización Mundial de la } \\
\text { Salud, 2019). }\end{array}$ & $\begin{array}{l}10 \text { million people at risk } \\
\text { (Organización Mundial } \\
\text { de la Salud, 2019). }\end{array}$ \\
\hline $\begin{array}{l}\text { Number of cases } \\
\text { on average by } \\
\text { population and } \\
\text { by Plasmodium } \\
\text { species }\end{array}$ & $\begin{array}{l}\text { 2010-2018: Number of cases } \\
\text { were reported on } \\
\text { average (Organización } \\
\text { Mundial de la Salud, 2019): } \\
\text { Suspected 386,368,994 } \\
\text { Indigenous: } P \text {. vivax } 290,112 \\
\text { Indigenous: } P \text { falciparum } 75,990 \\
\text { Indigenous: Mixed } 11,927 \\
\text { Indigenous: Other species } 68 \\
\text { Total: } P \text {. vivax } 1,742,687 \\
\text { Total: } P \text {. falciparum } 35,513,717 \\
\text { Total: Mixed cases } 310,815 \\
\text { Total: Other species } 53,100\end{array}$ & $\begin{array}{l}75 \% \text { belongs to } P \text {. vivax malaria. } \\
\text { 2010-2018: Were reported } \\
\text { on average (Organización } \\
\text { Mundial de la Salud, 2019): } \\
\text { Suspected } 7,152,884 \\
\text { Indigenous: } P \text {. vivax } 287,554 \\
\text { Indigenous: } P \text {. falciparum } 70,495 \\
\text { Indigenous: } P \text {. falciparum } 70,495 \\
\text { Indigenous: Mixed } 11,899 \\
\text { Indigenous: Other species } 55 \\
\text { Total: } P \text {. vivax } 9,184 \\
\text { Total: } P \text {. falciparum } 36,992 \\
\text { Total: Mixed cases } 2,471 \\
\text { Total: Other species } 78\end{array}$ & $\begin{array}{l}\text { 2019: } 77,172 \text { cases of } \\
\text { uncomplicated malaria and } \\
\text { 1,341 of complicated malaria } \\
\text { (Instituto Nacional de } \\
\text { Salud, 2019). } \\
\text { P. vivax } 48,5 \% \\
\text { P. falciparum 50,9\% } \\
\text { mixed cases } 0,9 \% \\
\text { Population most affected by } \\
\text { uncomplicated malaria Afro- } \\
\text { Colombians (41\%); Indigenous } \\
\text { (24\%); Miners ( } 7 \% \text { ); foreigners } \\
\text { (3\%), while Afro-Colombians } \\
\text { (21\%) and Indigenous are the } \\
\text { populations most affected by } \\
\text { complicated malaria (Ministerio } \\
\text { de Salud y Protección Social, } \\
2020 \text { ). }\end{array}$ \\
\hline $\begin{array}{l}\text { Total number of } \\
\text { reported cases }\end{array}$ & $\begin{array}{l}\text { 2010-2018: An average of } \\
230 \text { million cases were } \\
\text { reported (Organización Mundial } \\
\text { de la Salud, 2019). }\end{array}$ & $\begin{array}{l}\text { 2010-2018: } 686,000 \text { cases } \\
\text { were reported on average } \\
\text { (Organización Mundial } \\
\text { de la Salud, 2019). }\end{array}$ & $\begin{array}{l}\text { 2010-2019: Between } 40,000 \\
\text { and 118,000 cases are reported } \\
\text { per year (Instituto Nacional } \\
\text { de Salud, 2017). }\end{array}$ \\
\hline Average of Deaths & $\begin{array}{l}\text { 2010-2018: An average of } 442 \\
\text { thousand deaths were reported } \\
\text { (Organización Mundial } \\
\text { de la Salud, 2019). }\end{array}$ & $\begin{array}{l}\text { 2010-2018: an average of } \\
\text { 441 deaths were reported } \\
\text { (Organización Mundial } \\
\text { de la Salud, 2019). }\end{array}$ & $\begin{array}{l}\text { Deaths: } 2015(15) / 2016(36) \\
\text { /2017 (19)/2018 (9)/2019 (3) } \\
\text { (Instituto Nacional de Salud, } \\
\text { 2019; Instituto Nacional de } \\
\text { Salud, 2017). }\end{array}$ \\
\hline
\end{tabular}

It is relevant that the RDTs are stable, especially for regions in which there are high temperature and relative humidity conditions, which are typical conditions in many of the regions where there is malaria, so that these tests can be used and obtained reliable results. Moreover, compared with RDTs that detect pLDH, in general HRP2detecting RDTs are more sensitive and are less susceptible to degradation from heat and humidity during transport and storage (World Health Organization, 2015b).

Many of these $P$. falciparum RDTs have been fieldtested and different levels of sensitivity have been reported reporting that some RDTs have similar sensitivities to those commonly obtained by microscopy ( 100 parasites/ $\mu \mathrm{L})$ (Beadle et al., 1994; Garcia et al., 1996; Palmer et al., 1998). Furthermore, other studies have shown sensitivities well below the level required for operational use (Forney et al., 2001; 2003; Gaye et al., 1998; Huong et al., 2002; Iqbal et al., 2001; Jelinek et al., 1999; Mason et al., 2002; Rubio et al., 2001; Stow et al., 1999; Wongsrichanalai et al., 1999). Similarly, there are several studies that indicate little or low consistency in the results obtained for individual products or for the same product tested in different regions (Beadle et al., 1994; Forney et al., 2001; Gaye et al., 1998; Jelinek et al., 1999; Rubio et al., 2001; Stow et al., 1999; Wongsrichanalai et al., 1999; Banchongaksorn et al., 1997; Craig et al., 2002; Mharakurwa et al., 1997). Although there are reports of malaria RDTs that do not detect infections with high-level parasitaemia (Gaye et al., 1998; Iqbal et al., 2001; Stow et al., 1999; Wongsrichanalai et al., 1999; Birku et al., 1999; Playford and Walker, 2002), most of the reported variation has been from relatively low-level parasitaemia (100-500 parasites/ $\mu \mathrm{L}$ ) (Beadle et al., 1994; Huong et al., 2002; Stow et al., 1999; Bechem et al., 1999; Iqbal et al., 2002; Mills et al., 1999; Playford and Walker, 2002; Proux et al., 2001; Singh and Valecha, 2000), which generally results in clinical malaria in non-immune individuals, the causes of such variation being unknown (Baker et al., 2005). 
HRP2 and HRP3 are proteins routinely used in detection by Rapid Diagnostic Tests (RDT), test considered to be the most sensitive currently available and useful for the diagnosis of this disease in remote areas of endemic countries. The HRP2 concentration can be used to define severe malaria (plasma) and to quantify in vitro growth (laboratory culture) as well as to detect asymptomatic malaria in areas of low transmission, potentially allowing interventions at the public health level however, there have also been recent reports of pfhrp 2 gene deletions being found in parasites collected from several African countries, decreasing the effectiveness of these diagnostic tests (Poti et al., 2020).

In vivo, the two antigens (HRP2 and $\mathrm{pLDH}$ ) are cleared with different speeds, which appears to affect their specificities (notably, their ability to detect current infection) depending on the context. An evaluation in both high- and low-transmission areas in Uganda showed that median time for an HRP2 test to become negative after an effective treatment was 35-42 days, but that the median time to become negative for a pLDH test was only 2 days (Grandesso et al., 2016). This likely explained the higher specificity of the pLDH test $(94 \%)$ compared to HRP2 test $(80 \%)$ in the high-transmission area, while specificities were similarly high $(\sim 99 \%)$ in the low-transmission area. The higher specificity of pLDH tests was also seen in hospitalized children in Burkina Faso (Maltha et al., 2014). These findings have important implications in high-transmission environments, where interpretation of HRP2 tests can be difficult in the peak malaria season, leading to false positive results and hence unnecessary treatments (Coldiron et al., 2019; Arróspide et al., 2004; Moody, 2002).

Since microscopy is the best diagnostic alternative, RDTs should be considered as a second option, for endemic areas with fewer resources since, among others, they are very stable tests and their operation is not affected by high temperature or humidity conditions, conditions typical of the tropics, where there is a high prevalence of malaria. The ability to discern the Plasmodium species, in addition to being able to quantify the degree of parasitaemia make microscopy the most effective method, however, the simplicity and speed of RDTs are far from this gold standard: In just a few minutes, a staff with basic training can deposit the patient's blood drop in the device and make their diagnosis, on the other hand, to carry out microscopic techniques complex equipment, electricity and qualified personnel are required, which is not always easy in endemic third world countries (Barbadillo Ruiz, 2019).

\section{HRP2 and HRP3 Proteins}

HRP2 is a protein produced exclusively by $P$. falciparum; the gene that codes for this protein consists of a single subtelomeric copy located on chromosome 8 (Scherf and Mattei, 1992; Fontecha et al., 2019) of the $P$. falciparum genome, encoding an amino acid sequence containing $34 \%$ histidine, $37 \%$ alanine and $10 \%$ aspartic acid. PfHRP2 is a water-soluble of $60-105 \mathrm{kDa}$ protein (the gene has a $1073 \mathrm{pb}$ ), synthesized and present throughout the asexual life cycle and identified as a surface protein. This protein is exported by the parasite into the Red Blood Cells (RBC) cytosol and is also found circulating in the peripheral blood of infected individuals (Howard et al., 1986; Baker et al., 2010). As parasites rupture from the host cell, RBC cytosolic components, including HRP2, are released into the bloodstream. In plasma, HRP2 can reach $100 \mu \mathrm{g} / \mathrm{ml}$. Since its discovery (Wellems and Howard, 1986), many functions have been attributed to it, including hemozoin crystallization, actin formation, $\mathrm{T}$ cell suppression, glycosaminoglycan binding and procoagulation (Pal et al., 2016; Sullivan et al., 1996; Mashima et al., 2002; Benedetti et al., 2003; Ndonwi et al., 2011).

HRP2 has a high degree of stability and it has been verified that there is a positive correlation between its concentration in blood and the biomass of the parasite. Three histidine-rich proteins have been identified, the most relevant for the diagnostic field being PfHRP-2 and PfHRP-3. The first one is present in all infected red blood cells, while the second one has in its sequence repeated regions rich in histidine that are recognized by monoclonal antibodies to RDT that detect PfHRP-2 (Barbadillo Ruiz, 2019; Muñoz et al., 2015; Organización Mundial de la Salud, 2006).

PfHRP-2 is found in the digestive vacuole or in the cytoplasm of the parasite and plays a key role in the metabolism of $P$. falciparum. This protein actively facilitates the polymerization of the heme toxic group, resulting from the breakdown of the host hemoglobin, to form a malaria pigment, hemozoin, which is no longer toxic (Sullivan et al., 1996; Barbadillo Ruiz, 2019).

PfHRP-2 is expressed in gametocytes and all the erythrocytic stages of $P$. falciparum. The protein is released after the breakdown of the schizont and is therefore found in the blood of individuals infected with these parasites. In this way, even if the sequestered forms of $P$. falciparum cannot be found by microscopy, the presence of PfHRP2 can be detected in blood and this will contribute to establishing a positive diagnosis (Hayward et al., 2000).

HRP2 has been used as a biomarker for P. falciparum infection and forms the basis of many current rapid diagnostic tests (Dondorp et al., 2005; Parra et al., 1991). On postmortem analyses, HRP-2 has been observed to line the endothelial walls of blood vessels (Aikawa et al., 1990). Several correlative studies showed an association between plasma HRP2 levels and disease severity or development of Cerebral Malaria (CM) (Dondorp et al., 
2005; Hendriksen et al., 2013; Seydel et al., 2012; Hendriksen et al., 2012; Kariuki et al., 2014). Natural populations of HRP2-deficient Plasmodium falciparum parasites exist, though these tend to be in areas of low CM incidence (Pal et al., 2016; Gamboa et al., 2010; Koita et al., 2012; Kumar et al., 2013).

The PfHRP-3 gene (Histidine-Rich Protein 3), encodes the Histidine-3-Rich Protein (HRP3), which is also known as the small histidine-rich protein, the gene is located within the non-telomeric region of chromosome 13. PfHRP3 is a 30-35 kDa polypeptide, containing $30 \%$ histidine and $29 \%$ alanine. In the main protein-coding region there are two regions that have tandem-repeating units, these two regions are separated by a 72-nucleotide region that does not contain repeating units. It is not clear what the role of this protein is in the survival of the parasite (Sharma, 1988).

PfHRP-3 shares many similarities in structure and in function with PfHRP-2. Both contain a peptide that functions as a signal in exon 1, exon 2 encodes 75-90 nucleotide sequences of the histidine-rich amino acid. Although the composition in histidine in PfHRP-3 is slightly less than that of PfHRP-2 (28\% Vs. 34\%), both proteins share many repeats rich in histidine and alanine. These similarities suggest that these two genes are related and could come from duplication of an ancestral gene. The sequence of PfHRP-2 and PfHRP-3 is highly variable, so could give rise to a significant variation in the presence and frequency of epitopes recognized by monoclonal antibodies and therefore the impact on detection sensitivity (Baker et al., 2010).

Repeated histidine-rich repeats that are recognized by RDT monoclonal antibodies intended to detect PfHRP2 (Mouatcho and Goldring, 2013), are therefore useful for this purpose. However, immunochromatography devices that detect PfHRP2 have a number of limitations, for example, they are not capable of determining infections by other Plasmodium species, which limits the diagnostic possibilities. Second, RDTs that detect PfHRP2 are not helpful in monitoring antimalarial treatment. This is due to the persistence of the antigen in the peripheral blood circulation even after the elimination of the parasite, which can lead to false positives (Mayxay et al., 2001; Barbadillo Ruiz, 2019).

Another additional problem is the fact that there are worldwide-distributed $P$. falciparum strains that express genetic variation in the amino acid sequence of the protein.

\section{Genetic Variation of HRP Genes}

Baker et al. (2010), studied possible genetic variations in HRP in $75 P$. falciparum isolates from 19 countries. When performing the translation of amino acid sequences, PfHRP2 was observed that these sequences had consisted of variable numbers of repeats of 9, 6 and 3 amino acids, identifying a total of 14 different amino acid repeats from the PfHRP2 sequences. The composition, number and order of repeat types in PfHRP2 differed between individual parasites (Anders et al., 1986). 56 unique PfHRP2 sequences were detected; 43 were reported only once, while the remaining 13 sequences were seen in more than one isolated parasite; Nine of these 13 sequences were shared by isolates from the same country, while 4 were shared by isolates from different countries. All the different PfHRP2 sequences started with the type 1 repeat (AHHAHHVVAD) and ended with the type 12 repeat (AHHAAAHHEAATH). A relatively conserved repeat motif of types $7,8,2$ and 7 described in this study was present in the central region of the sequence in $87.8 \%(65 / 74)$ of the sequenced isolates. Of the 9 isolates hat did not have this motif, $7(9.5 \%)$ lacked only the first or last repetition of type 7 (Baker et al., 2005; Barbadillo Ruiz, 2019).

Nderu et al. (2019a), study 244 isolates collected in Kenya. The diversity of PfHRP2 and PfHRP3 was described as a function of frequency, occurrence and organization of the types of amino acid repeats in histidine-rich proteins. In this study, a unique distribution pattern of amino acid repeats was observed in both PfHRP-2 and PfHRP-3, identifying 228 and 124 different amino acid sequences of PfHRP2 and 3, respectively. Of these, 214 (94\%) PfHRP2 sequences and $81(65 \%)$ of PfHRP3 occurred only once. Thirtynine new repeats were identified for PfHRP2 and 20 for PfHRP3 and PfHRP-3 was found structurally to have a lower degree of genetic variability than PfHRP2 (Nderu et al., 2019a; 2019b; Barbadillo Ruiz, 2019). Figure 1 shows the structure, subcellular location and possible repeats found in the PfHRP genes.

Accordingly, genetic variability in histidine-rich proteins can lead to false negatives in diagnostic results with PfHRP-2 RDT.

This discovery is the result of studies carried out in the Amazon jungle of Peru and in India, which reveals the absence of the PfHRP-2 and 3 genes in the parasites of those regions (Barbadillo Ruiz, 2019; Gamboa et al., 2010; Kumar et al., 2013).

On the other hand, a study with 158 blood samples infected with $P$. falciparum was carried out in Honduras, Nicaragua and Guatemala. 25.8\% of the isolates did not present the partial coding region between exon 1 and 2 (intron 1) of PfHRP2 and $91.4 \%$ of the isolates lacked the homologous region of PfHRP3. Parasites from all three countries showed deletions from one or both of the genetic regions that code for these proteins. The highest proportion of exon 1-2 deletions in PfHRP2 was found in samples from Nicaragua $(30.9 \%)$, while isolates from Guatemala revealed the lowest number of deletions $(14.3 \%)$. Parasites collected in Honduras showed the 
highest proportion of exon 1-2 clearance in PfHRP3 $(96.2 \%)$. A relevant result was the finding of $27(21 \%)$ double negative isolates (negative PfHRP2 and negative PfHRP3). Most of the double negative parasites were detected in Honduras 13/52 (25\%), followed by Nicaragua 11/55 (20\%) and Guatemala 3/21 (14.3\%) (Fontecha et al., 2019; Barbadillo Ruiz, 2019). In another way, the presence of pfHRP-2/3 deletions in Tanzania and Uganda, along with reports of pfhrp2/3deleted parasites in neighboring countries, reinforces the need for systematic surveillance to monitor the reliability of RDTs in malaria-endemic countries.

Because $P$. falciparum isolates negative for PfHRP2 and PfHRP-3 have been reported in the neighboring regions of the Peruvian and Brazilian Amazon, a study was conducted in Colombia where 100 samples collected from six departments between 1999 and 2009 were included to detect the presence of PfHRP2, PfHRP3 and their flanking genes. Additionally, seven neutral microsatellites were used to determine the genetic background of these parasites. In total, 18/100 parasite isolates were found to have deleted PfHRP-2, most of which (14/18) were collected from the Department of Amazonas, which borders Peru and Brazil. Deletions of pfhrp3 were found in 52/100 samples collected from all regions of the country. The PfHRP2 PF3D7_0831900 and PF3D7_0831700 flanking genes were deleted in 22/100 and 1/100 samples, respectively. PfHRP3 flanking PF3D7_1372100 and PF3D7_1372400 genes were missing in 55/100 and 57/100 samples. Analysis of the structure of the microsatellite data indicated that the Colombian samples analyzed in this study belonged to four groups and were segregated mainly according to their geographical region. Most of the parasites with deletions in PfHRP2 were assigned to a single group and originated in the Amazonas Department, although some PfHRP2-negative parasites originated in the other three groups (Cordoba, Nariño and Valle). The presence of a high proportion of negative PfHRP2 isolates in the Colombian Amazon may have implications for the use of PfHRP2-based RDTs in the region and may explain the inconsistencies observed when conducting tests and trials based on PfHRP2 (Murillo Solano et al., 2015).

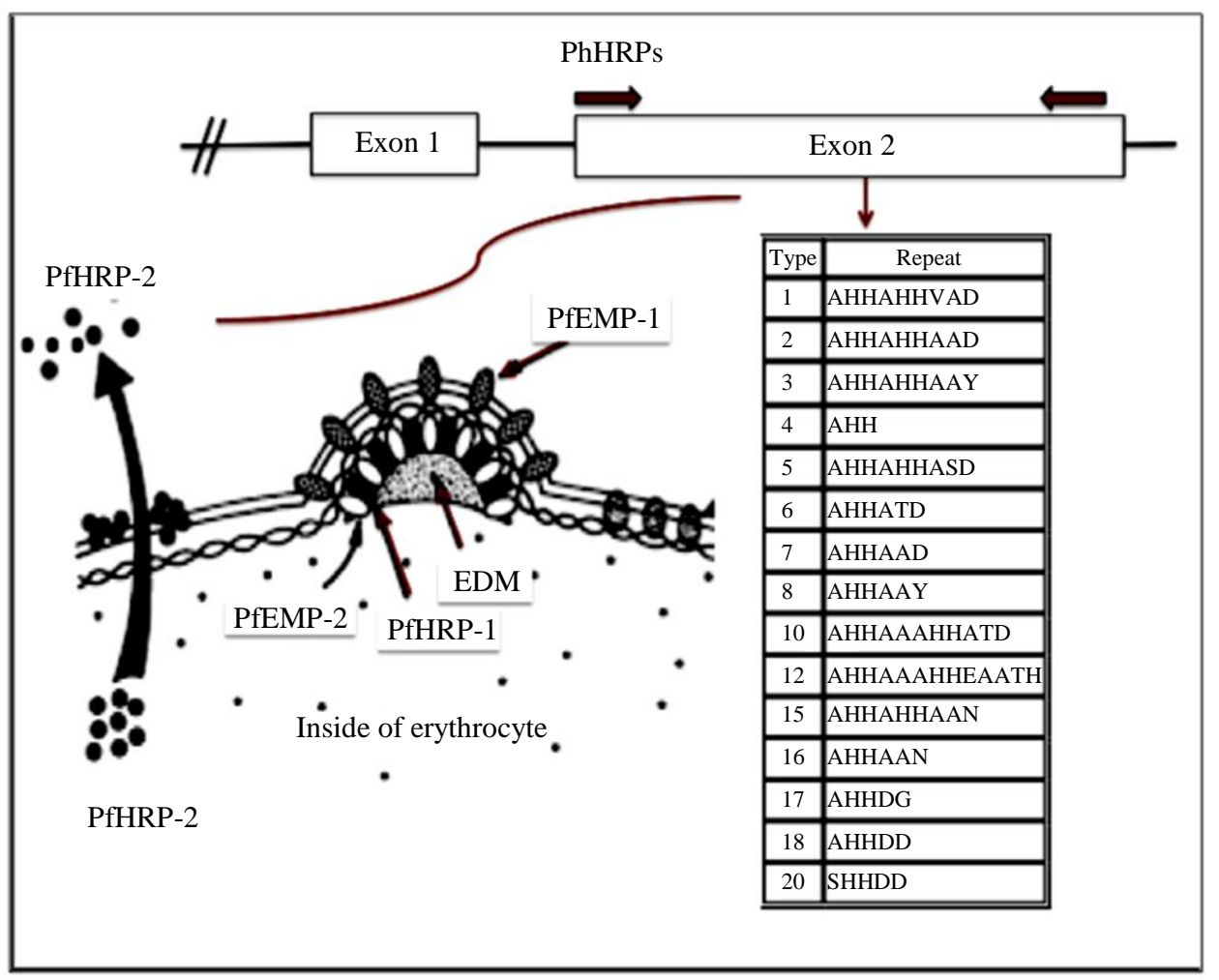

Fig. 1: Subcellular location and possible repeats found in the PfHRP genes. The scheme of a red blood cell and some of the proteins expressed by Plasmodium falciparum are presented (Modified of https://encrypted-tbn0.gstatic.com/images?q=tbn\%3AANd9GcR1AYefV7yWDyfBF2h2xWLhbkNIjVZBAh7Gg\&usqp=CAU). Also included the 20 repeat sequences found in exon 2 of the PfHRP-2 and 3 genes. PfEMP-1 = Plasmodium falciparum Erythrocyte membrane protein 1; PfEMP-2 = Plasmodium falciparum Erythrocyte Membrane Protein 2; PfHRP-1 = Plasmodium falciparum Histidine-Rich Protein 1; PfHRP-2 = Plasmodium falciparum Histidine-Rich Protein 2; EDM = Electrodense Material 
In a pilot study we carried out in Tarapacá (unpublished data), we found a $25 \%$ positivity using RDT for P. falciparum, while by PCR we obtained $39 \%$ positivity and were able to detect mixed infections in $7.14 \%$ of the samples, which were also confirmed by nucleic acid sequencing.

These results indicate the need to use microscopy and others diagnostic methods and RDT that detect different antigens.

Furthermore, it has been determined that the sensitivity of PfHRP-2 RDT is influenced by the presence or not of rheumatoid factor, since they seem to cause a cross reaction. There are studies that have tested how rheumatoid factor patients but not malaria patients tested positive for these RDTs. However, when rheumatoid factor was absorbed and the test was repeated, the result was negative. Some authors suggest that this fact is related to the type of antibody used in RDT. Thus, there is a cross reaction and false positive if $\mathrm{IgG}$ is used, but this does not occur if $\operatorname{IgM}$ is used, which does not bind to rheumatoid factor (Iqbal et al., 2001; Mishra et al., 1999; Barbadillo Ruiz, 2019).

The relationship between the detection of PfHRP 2 and the prozone effect has also been described, which consists of obtaining false negatives in immunological tests, due to an excess of antigens or antibodies. In the case of RDTPfHRP-2, it has been confirmed that elevated $P$. falciparum parasitemias can cause the aforementioned effect leading to false negatives (Gillet et al., 2009).

Despite these drawbacks, detection of HRP2 is the most common method of RDT, since Plasmodium falciparum is the most lethal species and is the only significant species in large parts of Africa. In addition, methods based on detection of HRP-2 have a sensitivity between 77 and $100 \%$ and a specificity between 83 and $93 \%$ with parasitemias $>100$ parasites $/ \mu \mathrm{L}$, making it in many cases a method comparable to that of microscopy to diagnose $P$. falciparum malaria (Zuluaga and Trujillo, 2010).

There are other diagnostic techniques, such as multiple PCR, which allows the detection of genomic DNA from all species. Conventional PCR amplification that allows detecting up to 3-4 parasites/ $\mu$ l and determining mixed infections, but it is a reserved technique to validate the results of the other techniques. On the other hand, there is the immunodiagnostic, which detects anti- $P$. falciparum antibodies in serum by immunofluorescence or enzyme immunoassay, which has low sensitivity and is used when microscopy is negative. However, the use of these techniques is less frequent since they are expensive and not available to all laboratories (Turrientes and López-Vélez, 2000; Torrús et al., 2015; Wilson, 2013).

The sensitivity and specificity of the conventional RDTs performed in the routine health facility consults and survey exit interviews were acceptable and there was no evidence of PfHRP2- and PfHRP3-deleted parasites. Monoinfections with non-falciparum malaria species comprised $<1 \%$ of the total malaria infections. Nearly all malaria antigen-positive patients had detectable PfHRP-2, confirming that this antigen remains an appropriate malaria diagnostic target in the surveyed provinces (Plucinski et al., 2019).

The pfHRP2 gene amino acid sequence and repeats have been shown to vary substantially across different geographic regions (Ramutton et al., 2012). Genomic sequencing of exons and flanking regions would provide more information on sequence diversity among these samples; similar pfHRP2-positive samples may have genetic diversity with implications for RDT detection. Although diversity in the pfHRP-2 gene has not been found to affect RDT affinity in samples with parasite densities of clinical significance (Bharti et al., 2016; Baker et al., 2010), it has been shown to affect RDT results at densities <200 parasites/ $\mu \mathrm{L}$ (Baker et al., 2005; Thomson et al., 2019).

In malaria endemic countries, the evaluation and monitoring of pfHRP-2/3 deletions and their impact must be carried out effectively and efficiently, along with many other public health and malaria control priorities. The WHO recommends the use of a protocol to implement surveys designed to measure parasites with pfHRP2 deletions among malaria suspects. The WHO guidelines state that if the prevalence of deletions of the pfHRP2 gene that cause HRP2-based false negative RDT results in a representative sample is greater than $5 \%$ (this value corresponds to the prevalence in which the benefits of Non-HRP2-based diagnostics to detect parasites with pfHRP2 deletions exceed the reduced sensitivity of these tools to detect wild-type parasites), HRP2-based RDTs should be replaced with a new diagnostic tool. In these cases, RDTs that target other antigens, such as those that detect pan-LDH or Pf-pLDH, can be used although these are less sensitive and heat stable than HRP2-based RDTs and this should be considered before using these RDTs (Thomson et al., 2019; World Health Organization, 2015a).

As mentioned before, the occurrence of pfHRP-2/3 gene deletions has a substantial risk to malaria control and could reverse the advances made through the rapid expansion of RDT uptake over the past decade. Prescribing adherence to test results, especially negative test results, has been a significant effort of RDT implementation. False-negative RDT results lead to underdiagnosis of malaria and if patients who are infected but test negative do not receive antimalarial treatment, severe disease and even death may result (Thomson et al., 2019; Gatton et al., 2017; Bruxvoort et al., 2017; Burchett et al., 2017). 


\section{But Why Continue Studying PfHRP2 and PfHRP3?}

PfHRP-2 and PfHRP-3 are located in the subtelomeric region of the chromosome and because they are in this region have great variability in their sequences and are normally subject to changes during episodes of recombination (Baker et al., 2010). The deletion of the PfHRP2 and PfHRP3 genes on chromosomes 8 and 13, respectively, in the $P$. falciparum parasites could be affecting the RDTs because the results could be false negatives in the absence of these genes. The target of RDT in parasites is a consequence of the deletion of these genes from the respective chromosomes. The deletion of these two genes has been previously reported in laboratory lines as Dd2 (deletion of PfHRP2), HB3 (deletion of PfHRP3) and 3BD5 with double deletion (Gamboa et al., 2010).

Agree with this, the importance of knowing the presence of those genes would allow us to evaluate which would be the best way to diagnose malaria and also know how effective rapid tests are. It is important to know if these genes are found in the samples (parasites) studied and to determine if the use of rapid tests to diagnose malaria in the country is reliable. In Colombia, the studies that have evaluated the genetic variability of these genes and their correlation with the efficacy of RDTs are limited and, due to the number of samples used, they do not allow establishing or extrapolating the results for the entire country. On the other hand, countries working towards the elimination of malaria will have to take into account the availability of diagnostic methods that maximize progress on the path towards elimination. Accordingly, in the elimination framework, WHO stands out through its support element "Taking advantage of innovations and expanding research, recommends: Basic research to foster innovation and the creation of new and improved instruments, including improved diagnostic tests".

Performance of HRP2-based RDTs can be affected by factors including antigenic variability of the target protein, antigen persistence in the bloodstream following elimination of parasites and parasite density below the RDT threshold of detection. The existence of parasites lacking pfhrp2 would affect RDT accuracy in a broader range of malaria-endemic regions and would have significant implications for RDT implementation, clinical case management and malaria control efforts.

\section{Conclusion}

Currently, there is little evidence to document the true extent of HRP mutations worldwide. In malaria endemic countries, it is necessary to assess the genetic variability of the genes discussed in this review in order to determine which mutations are present in each country so as to improve the diagnosis and interpretation of the results obtained by rapid and molecular tests, which will reduce the occurrence of false negatives and in the medium-long term, the improvement of malaria management programs and interventions.

\section{Acknowledgement and Funding Information}

The authors wish to acknowledge the financial support provided by the National Institute of Health of Colombia and to Colciencias for financing the research project, Code: 622177757170, “Eliminación de la malaria: Un reto para Colombia”.

\section{Author's Contributions}

María Luz Gunturiz: Wrote the article, participated with substantial contributions to study design and conception of the project "Eliminación de la malaria: Un reto para Colombia" and collaborated in the critical proofreading of the article and gave the final approval of the version to be submitted.

Pablo Enrique Chaparro, Gabriel Carrasquilla and Mónica Marcela Jiménez: Participated with substantial contributions to study design and conception of the project "Eliminación de la malaria: Un reto para Colombia" and collaborated in the critical proofreading of the article and gave the final approval of the version to be submitted.

\section{Ethics}

This article is original and contains unpublished material. The corresponding author confirms that all of the other authors have read and approved the manuscript and no ethical issues involved.

\section{References}

Aikawa, M., Iseki, M., Barnwell, J. W., Taylor, D., Oo, M. M., \& Howard, R. J. (1990). The pathology of human cerebral malaria. The American journal of tropical medicine and hygiene, 43(2_Part_2), 30-37.

Anders, R. F., Brown, G. V., Coppel, R. L., \& Kemp, D. J. (1986). Repeat structures in malaria antigens. Papua New Guinea medical journal, 29(1), 87-93.

Arróspide, N., Puray, M., Guzmán, E., Verano, M., Medina, S., Mendizábal, L., \& Gonzáles, S. (2004). Uso de pruebas rápidas inmunocromatográficas para la detección de Plasmodium falciparum en donantes de sangre en Perú. Revista Peruana de Medicina Experimental y Salud Pública, 21(2), 76-81.

Baker, J., Ho, M. F., Pelecanos, A., Gatton, M., Chen, N., Abdullah, S., ... \& Cunningham, J. (2010). Global sequence variation in the histidine-rich proteins 2 and 3 of Plasmodium falciparum: implications for the performance of malaria rapid diagnostic tests. Malaria journal, 9(1), 1-12. 
Baker, J., McCarthy, J., Gatton, M., Kyle, D. E., Belizario, V., Luchavez, J., ... \& Cheng, Q. (2005). Genetic diversity of Plasmodium falciparum histidine-rich protein 2 (PfHRP2) and its effect on the performance of PfHRP2-based rapid diagnostic tests. The Journal of infectious diseases, 192(5), 870-877.

Banchongaksorn, T., Prajakwong, S., Rooney, W., \& Vickers, P. (1997). Operational trial of ParaSight-F (dipstick) in the diagnosis of falciparum malaria at the primary health care level. The Southeast Asian journal of tropical medicine and public health, 28(2), 243.

Barbadillo Ruiz, A. (2019). Inmunodiagnóstico de la malaria. Tesis de grado. Facultad de Farmacia, Universidad Complutense.

Beadle, C., Long, G. W., McElroy, P. D., Hoffman, S. L., Weiss, W. R., Maret, S. M., \& Oloo, A. J. (1994). Diagnosis of malaria by detection of Plasmodium falciparum HRP-2 antigen with a rapid dipstick antigen-capture assay. The Lancet, 343(8897), 564-568.

Bechem, N. N., Leke, R. F., Tietche, F., \& Taylor, D. W. (1999). Evaluation of a rapid test for histidine rich protein 2 for diagnosis of Plasmodium falciparum infection in Cameroonian children. Transactions of the Royal Society of Tropical Medicine and Hygiene, 93(1), 46-46.

Benedetti, C. E., Kobarg, J., Pertinhez, T. A., Gatti, R. M., De Souza, O. N., Spisni, A., \& Meneghini, R. (2003). Plasmodium falciparum histidine-rich protein II binds to actin, phosphatidylinositol 4, 5bisphosphate and erythrocyte ghosts in a $\mathrm{pH}$ dependent manner and undergoes coil-to-helix transitions in anionic micelles. Molecular and biochemical parasitology, 128(2), 157-166.

Bharti, P. K., Chandel, H. S., Ahmad, A., Krishna, S., Udhayakumar, V., \& Singh, N. (2016). Prevalence of pfhrp2 and/or pfhrp3 gene deletion in Plasmodium falciparum population in eight highly endemic states in India. PLoS One, 11(8), e0157949.

Birku, Y., Welday, D., Ayele, D., \& Shepherd, A. (1999). Rapid diagnosis of severe malaria based on the detection of Pf-Hrp-2 antigen. Ethiopian medical journal, 37(3), 173-179.

Bruxvoort, K. J., Leurent, B., Chandler, C. I., Ansah, E. K., Baiden, F., Björkman, A., ... \& Elfving, K. (2017). The impact of introducing malaria rapid diagnostic tests on fever case management: a synthesis of ten studies from the ACT consortium. The American journal of tropical medicine and hygiene, 97(4), 1170-1179.

Burchett, H. E., Leurent, B., Baiden, F., Baltzell, K., Björkman, A., Bruxvoort, K., ... \& Hopkins, H. (2017). Improving prescribing practices with rapid diagnostic tests (RDTs): synthesis of 10 studies to explore reasons for variation in malaria RDT uptake and adherence. BMJ open, 7(3).
Chiodini, P. L., Bowers, K., Jorgensen, P., Barnwell, J. W., Grady, K. K., Luchavez, J., ... \& Bell, D. (2007). The heat stability of Plasmodium lactate dehydrogenase-based and histidine-rich protein 2based malaria rapid diagnostic tests. Transactions of the Royal Society of Tropical Medicine and Hygiene, 101(4), 331-337.

Coldiron, M. E., Assao, B., Langendorf, C., SayinzogaMakombe, N., Ciglenecki, I., de la Tour, R., ... \& Page, A. L. (2019). Clinical diagnostic evaluation of HRP2 and $\mathrm{pLDH}$-based rapid diagnostic tests for malaria in an area receiving seasonal malaria chemoprevention in Niger. Malaria journal, 18(1), 1-11.

Craig, M. H., Bredenkamp, B. L., Williams, C. V., Rossouw, E. J., Kelly, V. J., Kleinschmidt, I., ... \& Henry, G. F. J. (2002). Field and laboratory comparative evaluation of ten rapid malaria diagnostic tests. Transactions of the royal society of tropical medicine and hygiene, 96(3), 258-265.

Dondorp, A. M., Desakorn, V., Pongtavornpinyo, W., Sahassananda, D., Silamut, K., Chotivanich, K., ... \& Day, N. P. (2005). Estimation of the total parasite biomass in acute falciparum malaria from plasma PfHRP2. PLoS Med, 2(8), e204.

Fontecha, G., Pinto, A., Escobar, D., Matamoros, G., \& Ortiz, B. (2019). Genetic variability of Plasmodium falciparum histidine-rich proteins 2 and 3 in Central America. Malaria journal, 18(1), 1-10.

Forney, J. R., Magill, A. J., Wongsrichanalai, C., Sirichaisinthop, J., Bautista, C. T., Heppner, D. G., ... \& DeWitt, C. C. (2001). Malaria rapid diagnostic devices: performance characteristics of the ParaSight $\mathrm{F}$ device determined in a multisite field study. Journal of Clinical Microbiology, 39(8), 2884-2890.

Forney, J. R., Wongsrichanalai, C., Magill, A. J., Craig, L. G., Sirichaisinthop, J., Bautista, C. T., ... \& Andersen, E. M. (2003). Devices for rapid diagnosis of malaria: evaluation of prototype assays that detect Plasmodium falciparum histidine-rich protein 2 and a Plasmodium vivax-specific antigen. Journal of clinical microbiology, 41(6), 2358-2366.

Gamboa, D., Ho, M. F., Bendezu, J., Torres, K., Chiodini, P. L., Barnwell, J. W., ... \& Cheng, Q. (2010). A large proportion of $P$. falciparum isolates in the Amazon region of Peru lack pfhrp2 and pfhrp3: implications for malaria rapid diagnostic tests. PloS one, 5(1), e8091.

Garcia, M., Kirimoama, S., Marlborough, D., Leafasia, J., \& Rieckmann, K. H. (1996). Immunochromatographic test for malaria diagnosis. The Lancet, 347(9014), 1549.

Gatton, M. L., Dunn, J., Chaudhry, A., Ciketic, S., Cunningham, J., \& Cheng, Q. (2017). Implications of parasites lacking Plasmodium falciparum histidinerich protein 2 on malaria morbidity and control when rapid diagnostic tests are used for diagnosis. The Journal of Infectious Diseases, 215(7), 1156-1166. 
Gaye, O., Diouf, M., Dansokho, E. F., McLaughlin, G., \& Diallo, S. (1998). UsING PARASIGHT F9, ICT MALARIA PF9 AND MALARIA loG CELISA ${ }^{\circ}$ Assays. Parasite, 5, 189-192.

Gillet, P., Mori, M., Van Esbroeck, M., Van den Ende, J., \& Jacobs, J. (2009). Assessment of the prozone effect in malaria rapid diagnostic tests. Malaria journal, 8(1), 1-7.

Grandesso, F., Nabasumba, C., Nyehangane, D., Page, A. L., Bastard, M., De Smet, M., ... \& Etard, J. F. (2016). Performance and time to become negative after treatment of three malaria rapid diagnostic tests in low and high malaria transmission settings. Malaria journal, 15(1), 1-12.

Hayward, R. E., Sullivan, D. J., \& Day, K. P. (2000). Plasmodium falciparum: histidine-rich protein II is expressed during gametocyte development. Experimental parasitology, 96(3), 139-146.

Hendriksen, I. C., Mwanga-Amumpaire, J., Von Seidlein, L., Mtove, G., White, L. J., Olaosebikan, R., .. \& Karema, C. (2012). Diagnosing severe falciparum malaria in parasitaemic African children: a prospective evaluation of plasma Pf HRP2 measurement. PLoS Med, 9(8), e1001297.

Hendriksen, I. C., White, L. J., Veenemans, J., Mtove, G., Woodrow, C., Amos, B., ... \& Joseph, S. (2013). Defining Falciparum-Malaria-Attributable Severe Febrile Illness in Moderate-to-High Transmission Settings on the Basis of Plasma Pf HRP2 Concentration. The Journal of infectious diseases, 207(2), 351-361.

Houzé, S., Boly, M. D., Le Bras, J., Deloron, P., \& Faucher, J. F. (2009). Pf HRP2 and Pf LDH antigen detection for monitoring the efficacy of artemisininbased combination therapy (ACT) in the treatment of uncomplicated falciparum malaria. Malaria journal, 8(1), 211.

Howard, R. J., Uni, S., Aikawa, M., Aley, S. B., Leech, J. H., Lew, A. M., ... \& Taylor, D. W. (1986). Secretion of a malarial histidine-rich protein (Pf HRP II) from Plasmodium falciparum-infected erythrocytes. Journal of cell biology, 103(4), 1269-1277.

Huong, N. M., Davis, T. M., Hewitt, S., Van Huong, N., Uyen, T. T., Nhan, D. H., \& Cong, L. D. (2002). Comparison of three antigen detection methods for diagnosis and therapeutic monitoring of malaria: a field study from southern Vietnam. Tropical Medicine \& International Health, 7(4), 304-308.

Instituto Nacional de Salud. (2017). Informe de evento Malaria, Colombia. Inf del Even [Internet]. 2018; 19. https://www.ins.gov.co/Paginas/search.aspx?k=MA LARIA\#k=Informe\%20de\%20evento\%20Malaria

Instituto Nacional de Salud. (2019). Informe de evento Malaria, Colombia. https://www.ins.gov.co/Paginas/search.aspx?k=MALA RIA\#k=Informe\%20de\%20evento\%20Malaria
Iqbal, J., Hira, P. R., Sher, A., \& Al-Enezi, A. A. (2001). Diagnosis of imported malaria by Plasmodium lactate dehydrogenase (pLDH) and histidine-rich protein 2 (PfHRP-2)-based immunocapture assays. The American journal of tropical medicine and hygiene, 64(1), 20-23.

Iqbal, J., Khalid, N., \& Hira, P. R. (2002). Comparison of two commercial assays with expert microscopy for confirmation of symptomatically diagnosed malaria. Journal of Clinical Microbiology, 40(12), 4675-4678.

Jelinek, T., Grobusch, M. P., Schwenke, S., Steidl, S., Von Sonnenburg, F., Nothdurft, H. D., ... \& Löscher, T. (1999). Sensitivity and specificity of dipstick tests for rapid diagnosis of malaria in nonimmune travelers. Journal of clinical microbiology, 37(3), 721-723.

Kariuki, S. M., Gitau, E., Gwer, S., Karanja, H. K., Chengo, E., Kazungu, M., ... \& Newton, C. R. (2014). Value of Plasmodium falciparum histidinerich protein 2 level and malaria retinopathy in distinguishing cerebral malaria from other acute encephalopathies in Kenyan children. The Journal of infectious diseases, 209(4), 600-609.

Koita, O. A., Doumbo, O. K., Ouattara, A., Tall, L. K., Konaré, A., Diakité, M., ... \& Dolo, A. (2012). False-negative rapid diagnostic tests for malaria and deletion of the histidine-rich repeat region of the hrp2 gene. The American journal of tropical medicine and hygiene, 86(2), 194-198.

Kumar, N., Pande, V., Bhatt, R. M., Shah, N. K., Mishra, N., Srivastava, B., ... \& Anvikar, A. R. (2013). Genetic deletion of HRP2 and HRP3 in Indian Plasmodium falciparum population and false negative malaria rapid diagnostic test. Acta tropica, 125(1), 119-121.

Maltha, J., Guiraud, I., Lompo, P., Kaboré, B., Gillet, P., Van Geet, C., ... \& Jacobs, J. (2014). Accuracy of Pf HRP2 versus Pf-pLDH antigen detection by malaria rapid diagnostic tests in hospitalized children in a seasonal hyperendemic malaria transmission area in Burkina Faso. Malaria journal, 13(1), 20.

Mashima, R., Tilley, L., Siomos, M. A., Papalexis, V., Raftery, M. J., \& Stocker, R. (2002). Plasmodium falciparum Histidine-rich Protein-2 (PfHRP2) Modulates the Redox Activity of Ferriprotoporphyrin IX (FePPIX) PEROXIDASE-LIKE ACTIVITY OF THE PfHRP2-FePPIX COMPLEX. Journal of Biological Chemistry, 277(17), 1451414520 .

Mason, D. P., Kawamoto, F., Lin, K., Laoboonchai, A., \& Wongsrichanalai, C. (2002). A comparison of two rapid field immunochromatographic tests to expert microscopy in the diagnosis of malaria. Acta Tropica, 82(1), 51-59. 
Mayxay, M., Pukrittayakamee, S., Chotivanich, K., Looareesuwan, S., \& White, N. J. (2001). Persistence of Plasmodium falciparum HRP-2 in successfully treated acute falciparum malaria. Transactions of the Royal Society of Tropical Medicine and Hygiene, 95(2), 179-182.

Mharakurwa, S., Manyame, B., \& Shiff, C. J. (1997). Trial of the ParaSight-F test for malaria diagnosis in the primary health care system, Zimbabwe. Tropical Medicine \& International Health, 2(6), 544-550.

Mills, C. D., Burgess, D. C., Taylor, H. J., \& Kain, K. C. (1999). Evaluation of a rapid and inexpensive dipstick assay for the diagnosis of Plasmodium falciparum malaria. Bulletin of the World Health Organization, 77(7), 553.

Ministerio de Salud y Protección Social, 2020. Malaria. https://www.minsalud.gov.co/salud/publica/PET/Pa ginas/malaria.aspx

Mishra, B., Samantaray, J. C., Kumar, A., \& Mirdha, B. R. (1999). Study of false positivity of two rapid antigen detection tests for diagnosis of Plasmodium falciparum malaria. Journal of Clinical Microbiology, 37(4), 1233-1233.

Moody, A. (2002). Rapid diagnostic tests for malaria parasites. Clinical microbiology reviews, 15(1), 66-78.

Moreno, D. A. Q., Sánchez, L. M. M., Giraldo, M. A. A., Asprilla, L. E. V., \& Ríos, J. H. M. (2017). Malaria, enfermedad tropical de múltiples métodos diagnósticos. Archivos de Medicina (Manizales), 17(2), 402-414.

Mouatcho, J. C., \& Goldring, J. D. (2013). Malaria rapid diagnostic tests: challenges and prospects. Journal of medical microbiology, 62(10), 1491-1505.

Muñoz, J., Rojo-Marcos, G., Ramírez-Olivencia, G., Salas-Coronas, J., Treviño, B., Arellano, J. L. P., ... \& López-Vélez, R. (2015). Diagnóstico y tratamiento de la malaria importada en España: recomendaciones del Grupo de Trabajo de Malaria de la Sociedad Española de Medicina Tropical y Salud Internacional (SEMTSI). Enfermedades Infecciosas y Microbiología Clínica, 33(6), e1-e13.

Murillo Solano, C., Akinyi Okoth, S., Abdallah, J. F., Pava, Z., Dorado, E., Incardona, S., ... \& Barnwell, J. W. (2015). Deletion of Plasmodium falciparum histidine-rich protein 2 (pfhrp2) and histidine-rich protein 3 (pfhrp3) genes in Colombian parasites. PloS one, 10(7), e0131576.

Nderu, D., Kimani, F., Thiong'o, K., Karanja, E., Akinyi, M., Too, E., ... \& Velavan, T. P. (2019a). Plasmodium falciparum histidine-rich protein (PfHRP2 and 3) diversity in Western and Coastal Kenya. Scientific reports, 9(1), 1-9.

Nderu, D., Kimani, F., Karanja, E., Thiong'o, K., Akinyi, M., Too, E., ... \& Velavan, T. P. (2019b). Genetic diversity and population structure of Plasmodium falciparum in Kenyan-Ugandan border areas. Tropical Medicine \& International Health, 24(5), 647-656.
Ndonwi, M., Burlingame, O. O., Miller, A. S., Tollefsen, D. M., Broze Jr, G. J., \& Goldberg, D. E. (2011). Inhibition of antithrombin by Plasmodium falciparum histidine-rich protein II. Blood, The Journal of the American Society of Hematology, 117(23), 6347-6354.

Organización Mundial de la Salud. (2006). The use of malaria rapid diagnostic tests. Second edition. https://www.who.int/malaria/publications/usemalaria-rdts/en/

Organización Mundial de la Salud, (2019). Informe mundial sobre el paludismo 2019. https:/www.who.int/malaria/publications/worldmalaria-report-2019/report/es/

Osorio, L., Todd, J., \& Bradley, D. J. (2004). Travel histories as risk factors in the analysis of urban malaria in Colombia. The American journal of tropical medicine and hygiene, 71(4), 380-386.

Padilla, J. C., Chaparro, P. E., Molina, K., ArevaloHerrera, M., \& Herrera, S. (2015). Is there malaria transmission in urban settings in Colombia?. Malaria journal, 14(1), 1-9.

Padilla, J. C., Uribe, G. Á., Araújo, R. M., Narváez, P. C., \& Valencia, S. H. (2011). Epidemiology and control of malaria in Colombia. Memórias do Instituto Oswaldo Cruz, 106, 114-122.

Pal, P., Daniels, B. P., Oskman, A., Diamond, M. S., Klein, R. S., \& Goldberg, D. E. (2016). Plasmodium falciparum histidine-rich protein II compromises brain endothelial barriers and may promote cerebral malaria pathogenesis. MBio, 7(3).

Palmer, C. J., Lindo, J. F., Klaskala, W. I., Quesada, J. A., Kaminsky, R., Baum, M. K., \& Ager, A. L. (1998). Evaluation of the OptiMAL test for rapid diagnosis of Plasmodium vivax and Plasmodium falciparum malaria. Journal of clinical microbiology, 36(1), 203-206.

Parra, M. E., Evans, C. B., \& Taylor, D. W. (1991). Identification of Plasmodium falciparum histidine-rich protein 2 in the plasma of humans with malaria. Journal of clinical microbiology, 29(8), 1629-1634.

Playford, E. G., \& Walker, J. (2002). Evaluation of the ICT malaria $\mathrm{Pf} / \mathrm{Pv}$ and the OptiMal rapid diagnostic tests for malaria in febrile returned travellers. Journal of clinical microbiology, 40(11), 4166-4171.

Plucinski, M. M., Candrinho, B., Dimene, M., Colborn, J., Lu, A., Nace, D., ... \& Rogier, E. (2019). Assessing performance of HRP2 antigen detection for malaria diagnosis in Mozambique. Journal of clinical microbiology, 57(9), e00875-19.

Poti, K. E., Sullivan, D. J., Dondorp, A. M., \& Woodrow, C. J. (2020). HRP2: transforming malaria diagnosis, but with caveats. Trends in parasitology, $36(2), 112-126$. 
Proux, S., Hkirijareon, L., Ngamngonkiri, C., McConnell, S., \& Nosten, F. (2001). Paracheck-Pf $\AA$ : a new, inexpensive and reliable rapid test for $P$. falciparum malaria. Tropical Medicine \& International Health, 6(2), 99-101.

Ramutton, T., Hendriksen, I. C., Mwanga-Amumpaire, J., Mtove, G., Olaosebikan, R., Tshefu, A. K., ... \& Gesase, S. (2012). Sequence variation does not confound the measurement of plasma PfHRP2 concentration in African children presenting with severe malaria. Malaria journal, 11(1), 1-7.

Rubio, J. M., Buhigas, I., Subirats, M., Baquero, M., Puente, S., \& Benito, A. (2001). Limited level of accuracy provided by available rapid diagnosis tests for malaria enhances the need for PCR-based reference laboratories. Journal of Clinical Microbiology, 39(7), 2736-2737.

Scherf, A., \& Mattei, D. (1992). Cloning and characterization of chromosome breakpoints of Plasmodium falciparum: breakage and new telomere formation occurs frequently and randomly in subtelomeric genes. Nucleic acids research, 20(7), 1491-1496.

Seydel, K. B., Fox, L. L., Glover, S. J., Reeves, M. J., Pensulo, P., Muiruri, A., ... \& Taylor, T. E. (2012). Plasma concentrations of parasite histidine-rich protein 2 distinguish between retinopathy-positive and retinopathy-negative cerebral malaria in Malawian children. The Journal of infectious diseases, 206(3), 309-318.

Sharma, Y. D. (1988). Genomic organization, structure and possible function of histidine-rich proteins of malaria parasites. International Journal of Biochemistry, 20(5), 471-477.

Singh, N., \& Valecha, N. (2000). Evaluation of a rapid diagnostic test, 'Determine ${ }^{\mathrm{TM}}$ malaria $\mathrm{pf}^{\prime}$, in epidemic-prone, forest villages of central India (Madhya Pradesh). Annals of Tropical Medicine \& Parasitology, 94(5), 421-427.

Stow, N. W., Torrens, J. K., \& Walker, J. (1999). An assessment of the accuracy of clinical diagnosis, local microscopy and a rapid immunochromatographic card test in comparison with expert microscopy in the diagnosis of malaria in rural Kenya. Transactions of the Royal Society of Tropical Medicine and Hygiene, 93(5), 519-520.

Sullivan, D. J., Gluzman, I. Y., \& Goldberg, D. E. (1996). Plasmodium hemozoin formation mediated by histidine-rich proteins. Science, 271(5246), 219-222.

Thomson, R., Beshir, K. B., Cunningham, J., Baiden, F., Bharmal, J., Bruxvoort, K. J., ... \& Hopkins, H. (2019). pfhrp2 and pfhrp3 gene deletions that affect malaria rapid diagnostic tests for plasmodium falciparum: analysis of archived blood samples from 3 African countries. The Journal of infectious diseases, 220(9), 1444-1452.
Torrús, D., Carranza, C., Ramos, J. M., Rodríguez, J. C., Rubio, J. M., Subirats, M., \& Ta-Tang, T. H. (2015). Diagnóstico microbiológico de la malaria importada. Enfermedades Infecciosas y Microbiología Clínica, 33, 40-46.

Turrientes, M. C., \& López-Vélez, R. (2000). Aspectos prácticos del diagnóstico de laboratorio y profilaxis de la malaria. Madrid: Unidad de Medicina Tropical y Parasitología Clínica. Hospital Ramón y Cajal.

Wellems, T. E., \& Howard, R. J. (1986). Homologous genes encode two distinct histidine-rich proteins in a cloned isolate of Plasmodium falciparum. Proceedings of the National Academy of Sciences, 83(16), 6065-6069.

Wilson, M. L. (2013). Laboratory diagnosis of malaria: conventional and rapid diagnostic methods. Archives of Pathology and Laboratory Medicine, 137(6), 805-811.

Wongsrichanalai, C., Chuanak, N., Tulyayon, S., Thanoosingha, N., Laoboonchai, A., Thimasarn, K., ... \& Heppner, D. G. (1999). Comparison of a rapid field immunochromatographic test to expert microscopy for the detection of Plasmodium falciparum asexual parasitemia in Thailand. Acta tropica, 73(3), 263-273.

World Health Organization. (2015a). Guidelines for the treatment of malaria. World Health Organization.

World Health Organization. (2015b). Malaria rapid diagnostic test performance: results of WHO product testing of malaria RDTs: Round 6 (2014-2015).

World Health Organization. (2018). Protocol for estimating the prevalence of pfhrp $2 /$ pfhrp 3 gene deletions among symptomatic falciparum patients with false-negative rdt results. In Protocol for estimating the prevalence of pfhrp $2 /$ pfhrp3 gene deletions among symptomatic falciparum patients with false-negative RDT results.

Zuluaga, G. C., \& Trujillo, S. B. (2010). Malaria: consideraciones sobre su diagnóstico. Medicina \& Laboratorio, 16(07-08), 311-354. 